\title{
OBITUARY
}

\section{GAETANO DE SANCTIS}

Gaetano De Sanctis, the oldest of the honorary members of our Society, died in Rome on April 9, 1957. He was 86 years old. A pupil of K. J. Beloch in the early nineties of last century, he soon found his own way. His dissertation "Contributo alla storia ateniese dalla guerra lamiaca alla guerra cremonidea' ( 1893 ) established him as a scholar of international repute. His Atthis (1898; 2 ed. 1912) remains to date the best general study of archaic Athens. About 1900 De Sanctis, who had just been appointed a professor ordinarius in Turin, turned to Roman History. Mommsen appeared to him unsatisfactory both on the political and on the juridical side; but his main quarrel was with Pais' Storia di Roma which had been published in $\mathrm{r} 898$. He decided to produce a history of Rome which would combine archaeological and literary evidence and which would keep itself free both from blind traditionalism and arbitrary reconstructions. In this attempt he was signally successful. The first two volumes of the Storia dei Romani which appeared in 1907 and the third in two parts published in $1916-17$, were slowly but universally recognized as the soundest work on the subject in any language. It was also noticed that the author was free from uncritical admiration of Roman imperialism. By the time the first part of volume IV appeared in 1923 with its famous dedication 'A quei pochissimi che hanno parimente a sdegno d'essere oppressi e di farsi oppressori ', De Sanctis was already respected everywhere as a historian of great integrity and profound knowledge. He was also the head of a prosperous school of ancient historians. Honours followed-none of which gave him more pleasure than those coming from his English colleagues; and new responsibilities were thrown upon him. His editorship of the Rivista di Filologia (together with A. Rostagni) and of the section on Antiquity of the Enciclopedia Italiana was distinguished. But soon political and personal misfortunes affected his career. In 1929 an eye operation heralded approaching blindness. In 193 I he refused to take the Fascist oath, and the Government drove him out of the chair in the University of Rome to which he had been called two years before. A continuation of the Storia dei Romani seemed for many years impossible, but a stream of articles both on Greek and Roman subjects showed that the blind and persecuted historian had lost none of his intellectual and moral vigour. In 1939 he published a Storia dei Greci in two volumes. Though on a smaller scale than the Storia dei Romani, it was founded upon personal research and independent judgment : the final chapter on Socrates has some of the finest pages ever written by De Sanctis. A monograph on Pericles followed in 1944. In 1940 De Sanctis had taken up again the work on the Storia dei Romani. Two volumes were ready in 1945 , when the only copy of the manuscript was lost in a somewhat absurd episode of post-war disorganization. Undaunted, De Sanctis re-wrote the two volumes in extreme old age : one volume appeared in 1953, the other is in proof. The Italian government paid tribute to his intellectual and moral distinction by making him a professor for life in 1945 and by choosing him as one of the first five life members of the Italian Senate.

An attempt to examine De Sanctis' approach to ancient history has been made elsewhere $^{1}$; nor is there any need to give here a list of his publications. ${ }^{2}$ De Sanctis was a born researcher and a born teacher. He relished discussion and liked a good fight, but austerity, independence and courage were his most deeply ingrained qualities.

A. D. M.

1 See Rivista Storica Italiana, 69, I957, fasc. 2.

2 It can be found in an appendix to Studi di storia della storiografia greca (Firenze, La Nuova Italia, 195I). 